\title{
Impact of Artana mine on heavy metal pollution of the Marec river in Kosovo
}

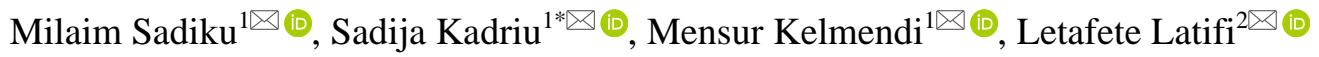 \\ ${ }^{1}$ University of Mitrovica, Mitrovicë, 40000, Kosovo \\ ${ }^{2}$ Hydrometeorological Institute of Kosovo, Prishtinë, 10000, Kosovo \\ *Corresponding author: e-mail sadija.kadriu@umib.net, tel. +38344736510
}

\begin{abstract}
Purpose. This paper aims to reflect the extent of the impact of the Artana mine on heavy metal pollution of the waters of the Marec river. Mineralogical pollution of this river resulted in almost total degradation of biota.

Methods. To be as realistic as possible in assessing the water quality of the Marec river and of a single spring located in the research area and used for drinking, we have applied the standard methods ISO 5667-6 for surface water and ISO 5667-11 for groundwater. The sampling and the quantity of the samples, as well as their transportation, was done in full compliance with the ISO 5667-1.3 method. Whereas, the conservation of samples taken for the determination of heavy metals is done according to the APHA conservation procedure. For the extraction (mineralization) of heavy metals in the samples taken, the EPA-3015A method was applied, while for the determination of the concentration of heavy metals the SAA (Atomic Absorption Spectrophotometry) measurement technique was applied.

Findings. As a result of the industrial activity of the Artana mine, it has been ascertained that the main causes of the pollution of the Marec river waters and the habitat around it is the mineral exploitation activity in this industrial complex. Analysis of water samples discharged from the mine, flotation and drainage of landfills reflect the real state of heavy metals concentration in the Marec river.

Originality. In order for the results to realistically reflect the degree of heavy metals concentration in the waters of this river, we have implemented existing and advanced analytical techniques.

Practical implications. The water samples from the Marec river were taken and analyzed in January and July 2020. The analysis performed showed significant exceedance of heavy metals concentration in all sampling sites located in the studied industrial area.
\end{abstract}

Keywords: mine of Artana, Marec river, landfill, streams, heavy metals, pollution

\section{Introduction}

The heavy metal pollution dates back to the $1930^{\text {s }}$, when the Trepça combine was founded, and at the same time exploitation of $\mathrm{Pb}, \mathrm{Zn}$ and other minerals began. Exploitation and processing of minerals, apart from economic development, resulted in the pollution of the environment [1] in Kosovo. It is known that from the $1970^{\text {th }}$ and through the $1990^{\text {th }}$, the Trepça combine was the greatest producer of $\mathrm{Pb}$, $\mathrm{Zn}, \mathrm{Cd}, \mathrm{Bi}, \mathrm{Ag}$, etc. in Europe. Therefore, the distortion of the ecological borderline between the industrial zone and the urban environment occurred due to rapid industrial development [2]. Exploitation of $\mathrm{Pb}-\mathrm{Zn}$ ore and other associated metals in the Artana mine (Novo Brdo) and other mines has begun since 1953 within the Industrial Complex "Trepça". The Artana ore field lies in the western part of the Rhodope mountain area, east of Kosovo, which is known as the Artana and Gollak mountain area and is characterized by a relief of 800-1335 $\mathrm{m}$ above sea level [3].

Numerous historical chronicles document that the opening and exploitation of this mine began in the time of the Roman Empire. It was used more intensively in the medieval period, first by the Ragusans (Dubrovnik), then by the German Sassanids. In early June 1455, it was conquered and taken into use by the Ottoman Empire [4], [5]. At the beginning of XX century, the mine was reopened by a British joint stock company based in London. From 1953 until today, it has operated and continues to operate within the "Trepça" combine.

The Artana mine, which was historically known as the gold and silver mine, according to some statistical data, has 4374116 tons of metal ore with the quality above cut-offgrade, including $\mathrm{Pb}=4.67 \%, \mathrm{Zn}=4.86 \%, \mathrm{Ag}=139.8 \mathrm{~g} / \mathrm{t}$ and $\mathrm{Au}=1.1 \mathrm{~g} / \mathrm{t}$. However, due to outdated technology of the flotation process, a large quantity of metals is dumped with 
industrial waste. Scientific research has already proven that mining water can contain a big amount of dissolved heavy metal ions. Besides pollution, it also causes significant loss of valuable metals [6].

Intensive exploitation and the use of the mine, especially during the $1970^{\mathrm{s}}-1990^{\mathrm{s}}$, when the ore production capacities reached 200000 tons/year, resulted in the formation of two large landfills with industrial waste, which contain high concentrations of lead, zinc and sulphur, as well as lower concentrations of other metals. In both landfills, the material leaks into the riverbed, which significantly increases the possibility of river pollution [7]. The landfills are located on the banks of the Marec River and are considered typical environmental hotspots. The first landfill (Fig. 1) covers an area of two hectares and contains 350000 tons of slag, while the second landfill (Fig. 2) is located $1.7 \mathrm{~km}$ from the first, occupies an area of four hectares and contains 2000000 tons of slag.

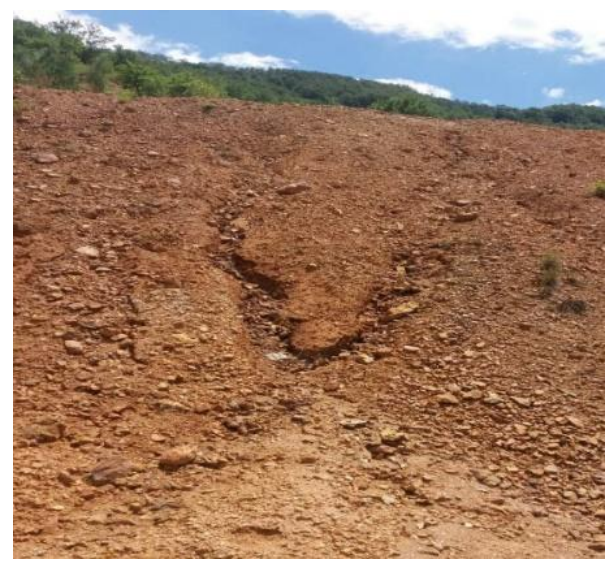

Figure 1. The first landfill

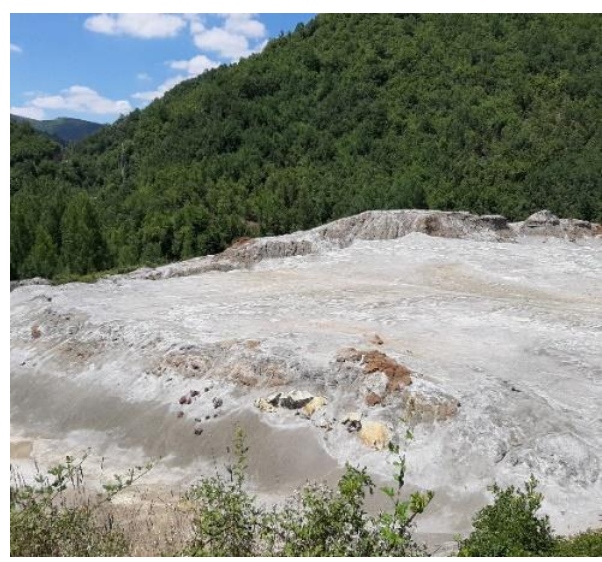

Figure 2. The second landfill

In terms of mineralogical composition, landfills are heterogeneous formations which are characterized by the following concentration of heavy metals: $\mathrm{Pb}=1-1.56 \%, \mathrm{Zn}=1.76-$ $3.22 \%, \mathrm{Ag}=20-110 \mathrm{~g} / \mathrm{t}, \mathrm{Au}=2-2.59 \mathrm{~g} / \mathrm{t}, \mathrm{FeS}_{2}=60-70 \%$ [3].

Located on the banks of the Marec river, these landfills, contrary to the modern standards of such constructions, are the main causes of pollution not only of the Marec river waters and groundwater, but also of the soil and air, thus degrading the environmental balance. As a result of such atmospheric processes as precipitation, sunning and erosive winds, landfills generate contaminants that pollute the environment in a cyclical way (air, land and water) [8]. In addi- tion to the harmful effect of these two landfills, the waters of the Marec river are directly polluted with heavy metals from a stream (Fig. 3), which carries the discharges resulting from the flotation process.

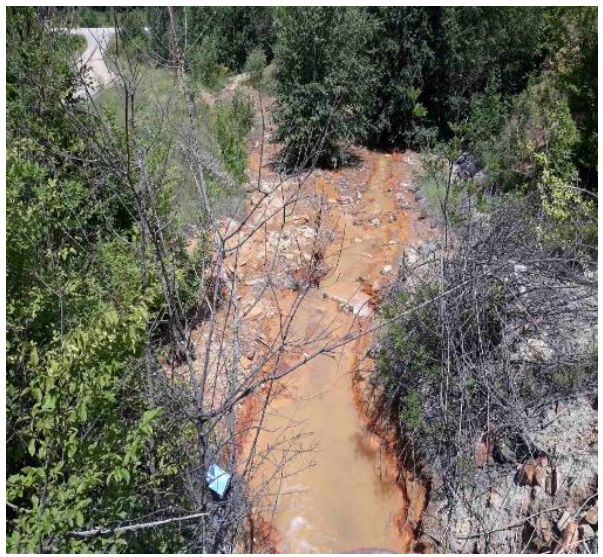

Figure 3. Polluted streams

The serious water pollution problem caused by mining operations is contamination with heavy metals, particularly copper, lead, cadmium and arsenic which occur naturally in trace quantities in the environment; while mining and smelting processes increase the presence of heavy metals to toxic levels [9]. Heavy metals contamination of water basins has received considerable attention worldwide due to not only toxicity but also to their persistence, abundance, and biomagnification in the environment and subsequent accumulation in aquatic habitats [10]. The Marec river, which divides the Gallap mountains, flows through the eastern part of Kosovo, more precisely the north-eastern part of the Anamorava region for $75 \mathrm{~km}$, being the left tributary of the Morava river in Binçë. The uncritical discharge of heavy metals that contaminate its water comes from mining and flotation.

The presence of two landfills on the banks of the river Marec, has motivated us to study the waters of this river in order to ascertain the degree of heavy metals concentration. Recently, anthropogenic activities have steadily increased the amount of heavy metals in aquatic ecosystems. Heavy metal pollution in aquatic system is growing at an alarming rate and have become a significant problem worldwide [11].

Heavy metals can pass into springs of drinking water, food products, and, due to high toxicity, they can bring about serious consequences for human health, so it is essential that their presence be maintained and always kept under control [12].

\section{Monitoring of the Marec river waters}

In order to get the most realistic idea of the water quality in the Marec river, resulting from pollution caused by industrial discharges, we focused our research on the analysis and identification of the degree of heavy metals concentration in these waters. For this reason, we have defined the monitoring network in the river flow comprising five sampling points, marked as: $S_{1}, S_{2}, S_{3}, S_{4}$ and $S_{5}$.

For the sake of water quality comparison, we also took a sample from a single source of drinking water in the research area, which we marked as $\mathrm{S}_{6}$.

The coordinates of the six sampling sites are presented in Table 1, and the geographic position of sampling points (monitoring network) is presented in Figure 4. 
Table 1. Geographical coordinates and altitude of sampling sites

\begin{tabular}{lccc}
\hline $\begin{array}{c}\text { Sampling } \\
\text { site }\end{array}$ & Length & Width & $\begin{array}{c}\text { Sea level, } \\
\mathrm{m}\end{array}$ \\
\hline $\mathrm{S}_{1}$ & $42^{\circ} 38^{\prime} 1.57^{\prime} \mathrm{N}$ & $21^{\circ} 23^{\prime} 35.35^{\prime \prime} \mathrm{E}$ & 699 \\
$\mathrm{~S}_{2}$ & $42^{\circ} 37^{\prime} 58.78^{\prime \prime N}$ & $21^{\circ} 25^{\prime} 48.41^{\prime \prime} \mathrm{E}$ & 664 \\
$\mathrm{~S}_{3}$ & $42^{\circ} 38^{\prime} 2.79^{\prime \prime N}$ & $21^{\circ} 25^{\prime} 44.07^{\prime \prime} \mathrm{E}$ & 646 \\
$\mathrm{~S}_{4}$ & $42^{\circ} 38^{\prime} 4.74^{\prime \prime N}$ & $21^{\circ} 25^{\prime} 44.62^{\prime \prime} \mathrm{E}$ & 649 \\
$\mathrm{~S}_{5}$ & $42^{\circ} 38^{\prime} 29.97^{\prime \prime N}$ & $21^{\circ} 26^{\prime} 25.99^{\prime \prime} \mathrm{E}$ & 621 \\
$\mathrm{~S}_{6}$ & $42^{\circ} 37^{\prime} 51.57^{\prime \prime} \mathrm{N}$ & $21^{\circ} 25^{\prime} 12.40^{\prime \prime} \mathrm{E}$ & 672 \\
\hline
\end{tabular}

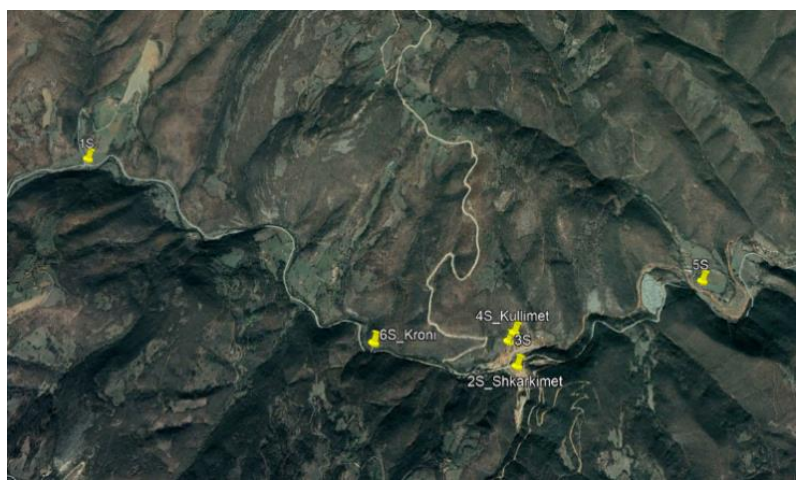

Figure 4. Monitoring network

Sampling site $S_{1}$ represents the Marec river before the discharge of mine waters. This sampling site was spotted in the Marec river, approximately $3.8 \mathrm{~km}$ before the discharge of the Artana mine waters, which means that the water in this sampling site, should not have industrial pollution apart from urban pollution.

$\mathrm{S}_{2}$ - discharges from the mine. This sampling site is the key problem for this research, because it represents the waters which are pumped directly from the mine horizons and are discharged into the Marec river through the stream.

$\mathrm{S}_{3}$ - Marec river after mine discharges. In order to have a more realistic picture regarding the impact of water discharged from the mine on the water quality of the Marec river, we have located the $S_{3}$ sampling site at a distance of 10 meters from the previous point.

$\mathrm{S}_{4}-$ drainage water from the first landfill. The sampling site in question represents the quality of water drained from the industrial waste of the mine landfill located on the banks of the Marec river. Agricultural land along the river banks is at risk of heavy metals pollution [13].

$\mathrm{S}_{5}-$ Marec river after the second landfill. This sampling site was spotted in the flow of the Marec river after the second landfill which is located at a distance of $1.7 \mathrm{~km}$ from the first landfill.

$\mathrm{S}_{6}-$ source of drinking water. The natural spring represents the water located in the research area, near the road, which locals and passers-by use for drinking. The issue of having sufficient volume of drinking water in many Kosovo settlements, as in many other countries in the world, has been and remains the basic problem for maintaining life quality in the geographical area where humans wish to build and organize their settlements [14]. That is why it is important to verify the presence or absence of heavy metals in the waters of this spring.

\section{Materials and methods}

To be as objective as possible in assessing the quality of water taken as samples for this research, we based on the standards ISO 5667-6 [15] for surface water and ISO 566711 [16] for groundwater. The method of sampling, the quantity of the samples taken as well as the mode of their transportation and the maximum time of the sample exposure before the chemical analysis, comply with the ISO 5667-1,3 [17], [18]. The conservation of samples for determination of certain parameters was done in accordance with the APHA conservation procedure [19]. Method EPA-3015A [20] was applied for the preparation of water samples for measurement-extraction (mineralization) of heavy metals, while SAA (Atomic Absorption Spectrophotometry) measurement techniques were applied for determination of heavy metals concentration. Concentrations of the following metals in water have been determined: $\mathrm{Pb}, \mathrm{Zn}, \mathrm{Ni}, \mathrm{Fe}, \mathrm{Cd}, \mathrm{Cu}, \mathrm{Mn}$ and $\mathrm{Cr}$. The experimental part was conducted in the laboratory of environmental analysis of HMIK (Hydrometeorological Institute of Kosovo).

\section{Results and discussion}

To do a more realistic assessment of the degree of heavy metals $(\mathrm{Pb}, \mathrm{Zn}, \mathrm{Ni}, \mathrm{Fe}, \mathrm{Cd}, \mathrm{Cu}, \mathrm{Mn}$ and $\mathrm{Cr}$ ) concentration in industrial discharge waters, in the waters of the Marec river and in the waters of the source (kroit), used for beverages, we based on reference values (MAV).

For samples taken at sampling sites $\mathrm{S}_{2}$ (discharges from the mine) and $\mathrm{S}_{4}$ (water draining from the landfill), we followed the Administrative Instruction of MESP-No. 30/2014 of Kosovo, which deals with the allowed limit values of polluted water parameters, which can be discharged into the public sewage network and the affected environment [21].

Regarding the concentration of heavy metals in the Marec River waters, presented in samples $S_{1}, S_{3}$ and $S_{5}$, we departed from the maximum allowed values for some heavy metals in the surface waters as identified in the Legislative Decree of 11 May 1999 No. 15232 [22]. Whereas, for the sample from the source of drinking water (sampling site $\mathrm{S}_{6}$ ), the results were compared with the Administrative Instruction of Kosovo $16 / 2012$, which has to do with the quality of water for human consumption [23]. Water samples were taken during January-July 2020 and are presented in Tables 2-5.

Table 2. Concentration of heavy metals according to sampling sites in the Marec river, January 2020

\begin{tabular}{lcccccccc}
\hline \multicolumn{1}{c}{ Heavy metals } & Unit & $\begin{array}{c}\text { MAV Decree } \\
\text { 1999_No. 15232 }\end{array}$ & \multirow{2}{*}{$\mathrm{S}_{1}$} & \multirow{2}{*}{$\mathrm{S}_{3}$} & \multirow{2}{*}{$\mathrm{S}_{5}$} & MAV & \multirow{2}{*}{ UA_30_2014 } & $\mathrm{S}_{2}$ \\
\hline Copper $\left(\mathrm{Cu}^{2+}\right)$ & $\mathrm{mg} / \mathrm{L}$ & 1.00 & 0.0018 & 0.102 & 0.124 & 0.50 & 0.548 & 0.710 \\
Zink $\left(\mathrm{Zn}^{2+}\right)$ & $\mathrm{mg} / \mathrm{L}$ & 3.00 & $<0.001$ & 0.088 & 0.102 & 1.00 & 0.928 & 4.882 \\
Cadmium $\left(\mathrm{Cd}^{2+}\right)$ & $\mathrm{mg} / \mathrm{L}$ & 0.005 & $<0.001$ & 0.006 & 0.009 & 0.02 & 0.353 & 0.520 \\
Lead $\left(\mathrm{Pb}^{2+}\right)$ & $\mathrm{mg} / \mathrm{L}$ & 0.01 & 0.010 & 0.020 & 0.027 & 0.50 & 0.483 & 3.103 \\
Nickel $\left(\mathrm{Ni}^{2+}\right)$ & $\mathrm{mg} / \mathrm{L}$ & 0.02 & 0.003 & 0.032 & 0.040 & 0.50 & 0.363 & 2.258 \\
Chrome $\left(\mathrm{Cr}^{3+}\right)$ & $\mathrm{mg} / \mathrm{L}$ & 0.05 & 0.005 & 0.010 & 0.012 & 1.00 & 0.093 & 0.202 \\
Manganese $\left(\mathrm{Mn}^{2+}\right)$ & $\mathrm{mg} / \mathrm{L}$ & 0.05 & $<0.001$ & 1.340 & 10.540 & 2.00 & 36.500 & 680.000 \\
Iron $\left(\mathrm{Fe}^{2+}\right)$ & $\mathrm{mg} / \mathrm{L}$ & 0.20 & 0.018 & 1.202 & 30.030 & 2.00 & 53.420 & 1264.000 \\
\hline
\end{tabular}


The results obtained for January and presented in Table 2, depict this situation.

In the sampling site $\mathrm{S}_{1}$, except for $\mathrm{Pb}$ (Fig. 4), which is present in the allowed limit value, we did not observe exceeding reference values of other metals.

In $\mathrm{S}_{2}$, exceeding reference values were observed for $\mathrm{Cu}-$ $0.548 \mathrm{mg} / \mathrm{L}, \mathrm{Cd}-0.353 \mathrm{mg} / \mathrm{L}, \mathrm{Mn}-36.5 \mathrm{mg} / \mathrm{L}$ and $\mathrm{Fe}$ with $53.42 \mathrm{mg} / \mathrm{L}$, while the presence of $\mathrm{Zn}$ and $\mathrm{Pb}$ was in the proximity of the allowed limit value.

Sampling site $\mathrm{S}_{3}$ provided the exceeding reference values for $\mathrm{Cd}-0.006 \mathrm{mg} / \mathrm{L}, \mathrm{Pb}-0.020 \mathrm{~g} / \mathrm{L}, \mathrm{Ni}-0.032 \mathrm{mg} / \mathrm{L}$, $\mathrm{Mn}-1.34 \mathrm{mg} / \mathrm{L}$ and $\mathrm{Fe}-1.202 \mathrm{mg} / \mathrm{L}$, while the presence of other heavy metals in this sampling was within the allowed limit values.

In the $\mathrm{S}_{4}$ sampling site, except for $\mathrm{Cr}$, exceeding reference values we observed for all heavy metals: $\mathrm{Cu}-0.710 \mathrm{mg} / \mathrm{L}$, $\mathrm{Zn}-4.882 \mathrm{mg} / \mathrm{L}, \mathrm{Cd}-0.520 \mathrm{mg} / \mathrm{L}, \mathrm{Pb}-3.103 \mathrm{mg} / \mathrm{L}, \mathrm{Ni}-$ $2.258 \mathrm{mg} / \mathrm{L}$. Alarming exceedances of the reference values, were encountered for $\mathrm{Mn}$ at $680 \mathrm{mg} / \mathrm{L}$ and $\mathrm{Fe}$ at $1264 \mathrm{mg} / \mathrm{L}$. So, discharge of untreated or insufficiently treated wastewater, containing a significant amount of heavy metal ions, causes great damage to the environment [24].

In the $\mathrm{S}_{5}$ sampling site, exceeding heavy metals limit reference values were observed for $\mathrm{Cd}-0.009 \mathrm{mg} / \mathrm{L}, \mathrm{Pb}-0.027$ $\mathrm{mg} / \mathrm{L}, \mathrm{Ni}-0.040 \mathrm{mg} / \mathrm{L}$, while more pronounced exceedances were encountered for $\mathrm{Mn}$ with $10.54 \mathrm{mg} / \mathrm{L}$ and $\mathrm{Fe}$ with $30.03 \mathrm{mg} / \mathrm{L}$. Table 2 shows that the concentrations of $\mathrm{Cu}, \mathrm{Zn}$ and $\mathrm{Cr}$ in this sampling site are within the allowed limits.
Table 3. Concentration of heavy metals in the source of drinking water, January 2020

\begin{tabular}{lccc}
\hline \multicolumn{1}{c}{ Heavy metals } & Unit & VML & \multirow{2}{*}{ UA_16_2012 } \\
\hline Copper $\left(\mathrm{Cu}^{2+}\right)$ & $\mathrm{mg} / \mathrm{L}$ & 2.00 & 0.002 \\
Zink $\left(\mathrm{Zn}^{2+}\right)$ & $\mathrm{mg} / \mathrm{L}$ & $0.50^{*}$ & 0.006 \\
Cadmium $\left(\mathrm{Cd}^{2+}\right)$ & $\mathrm{mg} / \mathrm{L}$ & 0.005 & 0.006 \\
Lead $\left(\mathrm{Pb}^{2+}\right)$ & $\mathrm{mg} / \mathrm{L}$ & 0.01 & 0.011 \\
Nickel $\left(\mathrm{Ni}^{2+}\right)$ & $\mathrm{mg} / \mathrm{L}$ & 0.02 & 0.012 \\
Chrome $\left(\mathrm{Cr}^{3+}\right)$ & $\mathrm{mg} / \mathrm{L}$ & 0.05 & 0.003 \\
Manganese $\left(\mathrm{Mn}^{2+}\right)$ & $\mathrm{mg} / \mathrm{L}$ & 0.05 & 0.011 \\
Iron $\left(\mathrm{Fe}^{2+}\right)$ & $\mathrm{mg} / \mathrm{L}$ & 0.20 & 0.020 \\
\hline
\end{tabular}

$* \mathrm{Zn}$ reference value is based on United States Environmental Protection Agency (US EPA)

Table 3 shows the January 2020 data about the quality of drinking water, taken for analysis from the fountain (spring) located in the research area that residents and casual passersby use for drinking. In this sampling site, marked as $\mathrm{S}_{6}$, except for $\mathrm{Cd}$ in the amount of $0.006 \mathrm{mg} / \mathrm{L}$ and $\mathrm{Pb}-0.011 \mathrm{mg} / \mathrm{L}$, we have not observed exceeding limit reference values for other heavy metals. Lead is toxic to the central and peripheral nervous systems causing neurological and behavioral effects. Lead consumption in high quantity may cause hearing loss, hypertension and eventually may lead to fatal consequences [25]. When cadmium enters the human body, it is accumulated in kidneys and can cause problems resulting in kidney dysfunction. Brittle bones, lung cancer and acute pneumonia are other health effects that arise from cadmium exposure [26].

Table 4. Concentration of heavy metals in the source of drinking water, July 2020

\begin{tabular}{lcccccccc}
\hline \multicolumn{1}{c}{ Heavy metals } & \multirow{2}{*}{ Unit } & \multirow{2}{*}{ No. 15232 } & \multirow{2}{*}{$\mathrm{S}_{1}$} & $\mathrm{~S}_{3}$ & $\mathrm{~S}_{5}$ & $\mathrm{VML}$ & \multirow{2}{*}{$\mathrm{S}_{2}$} & $\mathrm{~S}_{4}$ \\
\hline Copper $\left(\mathrm{Cu}^{2+}\right)$ & $\mathrm{mg} / \mathrm{L}$ & 1.00 & 0.002 & 0.116 & 0.141 & 0.50 & 0.559 & 0.740 \\
Zink $\left(\mathrm{Zn}^{2+}\right)$ & $\mathrm{mg} / \mathrm{L}$ & 3.00 & $<0.001$ & 0.096 & 0.114 & 1.00 & 0.935 & 4.898 \\
Cadmium $\left(\mathrm{Cd}^{2+}\right)$ & $\mathrm{mg} / \mathrm{L}$ & 0.005 & $<0.001$ & 0.009 & 0.012 & 0.02 & 0.378 & 0.528 \\
Lead $\left(\mathrm{Pb}^{2+}\right)$ & $\mathrm{mg} / \mathrm{L}$ & 0.01 & 0.011 & 0.028 & 0.035 & 0.50 & 0.492 & 3.119 \\
Nickel $\left(\mathrm{Ni}^{2+}\right)$ & $\mathrm{mg} / \mathrm{L}$ & 0.02 & 0.005 & 0.048 & 0.061 & 0.50 & 0.397 & 2.284 \\
Chrome $\left(\mathrm{Cr}^{3+}\right)$ & $\mathrm{mg} / \mathrm{L}$ & 0.05 & 0.007 & 0.013 & 0.018 & 1.00 & 0.102 & 0.221 \\
Manganese $\left(\mathrm{Mn}^{2+}\right)$ & $\mathrm{mg} / \mathrm{L}$ & 0.05 & $<0.001$ & 1.520 & 11.720 & 2.00 & 37.800 & 710.000 \\
Iron $\left(\mathrm{Fe}^{2+}\right)$ & $\mathrm{mg} / \mathrm{L}$ & 0.20 & 0.021 & 1.228 & 31.050 & 2.00 & 54.210 & 1306.000 \\
\hline
\end{tabular}

The results obtained for July and presented in Table 4 reflect the following situation. In sampling site $S_{1}$ (Fig. 5), except for $\mathrm{Pb}$ with concentration of $0.011 \mathrm{mg} / \mathrm{L}$, we did not observe exceeding reference values for other heavy metals.

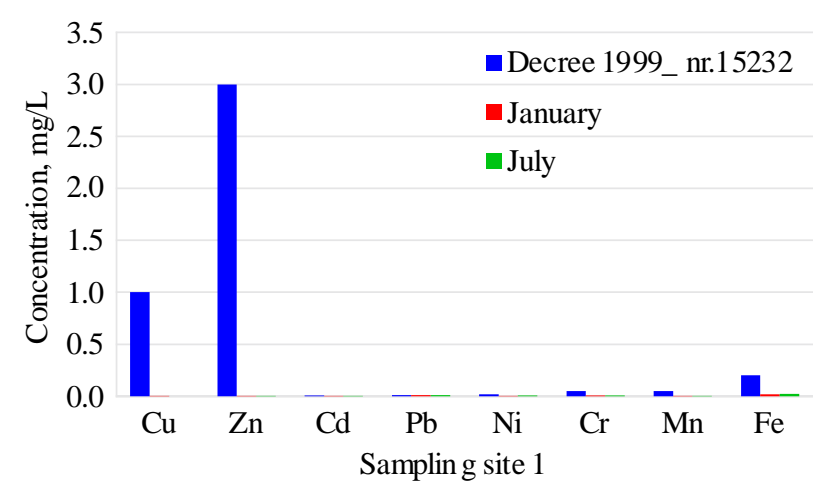

Figure 5. Concentration of heavy metals in sampling site $S_{I}$ (January, July 2020)

In $\mathrm{S}_{2}$, exceeding reference values were registered for $\mathrm{Cu}$ $0.559 \mathrm{mg} / \mathrm{L}$, and $\mathrm{Cd}-0.378 \mathrm{mg} / \mathrm{L}$, while the most pronounced concentrations were encountered for $\mathrm{Mn}-$
$37.8 \mathrm{mg} / \mathrm{L}$ and $\mathrm{Fe}-54.21 \mathrm{mg} / \mathrm{L}$ (Fig. 6). The presence of $\mathrm{Zn}$ and $\mathrm{Pb}$ was within the permissible limit value.

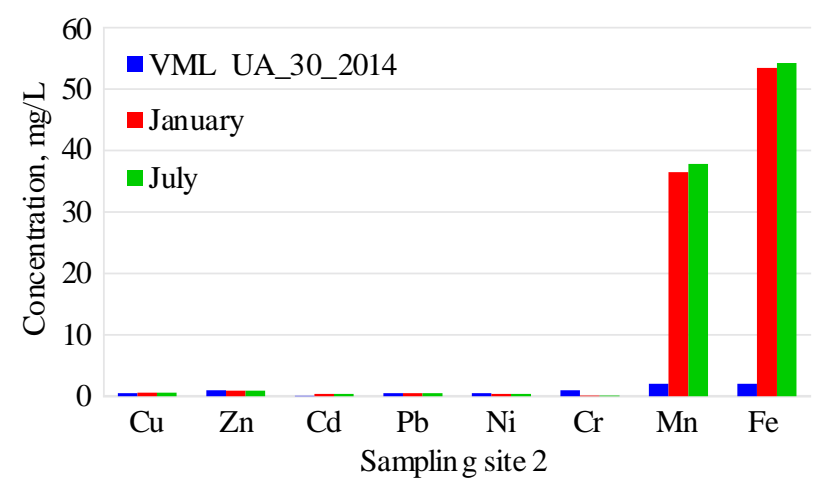

Figure 6. Concentration of heavy metals in sampling site $S_{2}$ (January, July 2020)

Sampling site $\mathrm{S}_{3}$ demonstrated exceeding reference values for $\mathrm{Cd}-0.009 \mathrm{mg} / \mathrm{L}, \mathrm{Pb}-0.028 \mathrm{~g} / \mathrm{L}, \mathrm{Ni}-0.048 \mathrm{mg} / \mathrm{L}$, $\mathrm{Mn}-1.52 \mathrm{mg} / \mathrm{L}$ and $\mathrm{Fe}-1.228 \mathrm{mg} / \mathrm{L}$ (Fig. 7), while the presence of other heavy metals in this sampling was within reference values. 


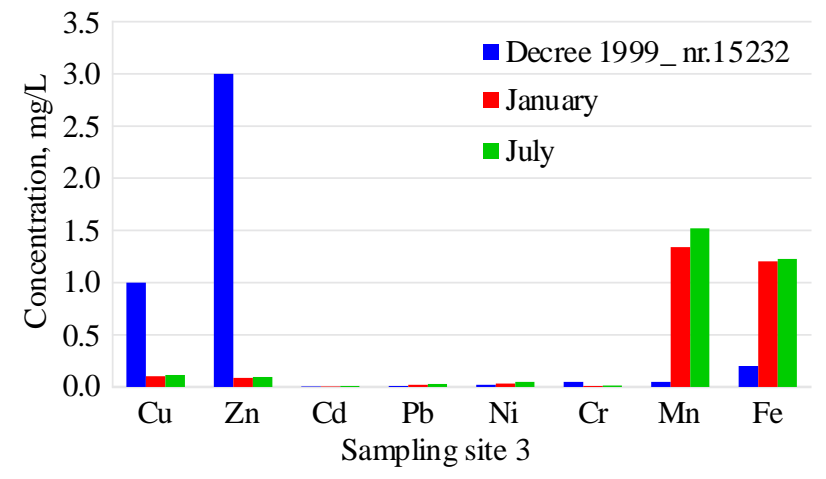

Figure 7. Concentration of heavy metals in sampling site $\mathrm{S}_{3}$ (January, July 2020)

In sampling site $\mathrm{S}_{4}$, exceeding reference values were re-gistered for $\mathrm{Cu}-0.740 \mathrm{mg} / \mathrm{L}, \mathrm{Zn}-4.898 \mathrm{mg} / \mathrm{L}, \mathrm{Cd}-$ $0.528 \mathrm{mg} / \mathrm{L}, \mathrm{Pb}-3.119 \mathrm{mg} / \mathrm{L}, \mathrm{Ni}-2.284 \mathrm{mg} / \mathrm{L}$. Alarming exceedances of the reference values were observed for $\mathrm{Mn}$ at $710 \mathrm{mg} / \mathrm{L}$ and $\mathrm{Fe}$ at $1306 \mathrm{mg} / \mathrm{L} \mathrm{(Fig.} \mathrm{8).}$

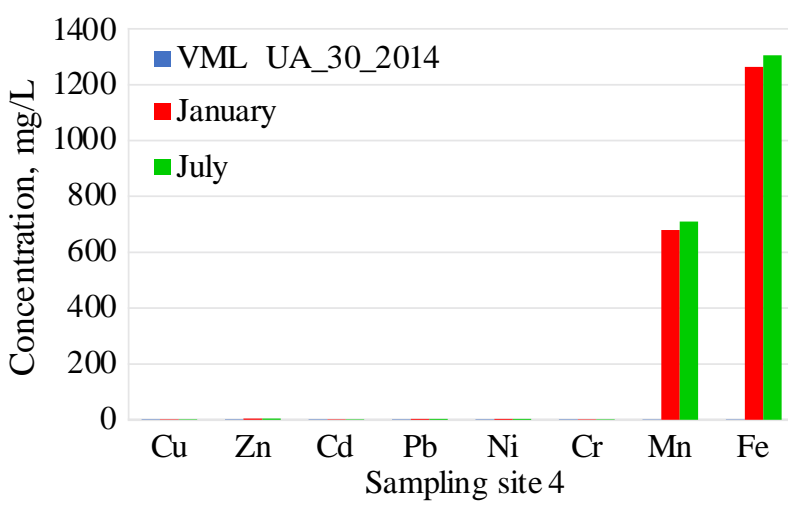

Figure 8. Concentration of heavy metals in sampling site $\mathrm{S}_{4}$ (January, July 2020)

Sampling site $\mathrm{S}_{5}$ demonstrated exceeding reference values for $\mathrm{Cd}-0.012 \mathrm{mg} / \mathrm{L}, \mathrm{Pb}-0.035 \mathrm{mg} / \mathrm{L}, \mathrm{Ni}-0.061 \mathrm{mg} / \mathrm{L}$, while the most pronounced exceedances were encountered for $\mathrm{Mn}$ at $11.72 \mathrm{mg} / \mathrm{L}$ and $\mathrm{Fe}$ at $31.05 \mathrm{mg} / \mathrm{L}$ (Fig. 9). $\mathrm{Cu}, \mathrm{Zn}$ and $\mathrm{Cr}$ presence complies with the reference values.

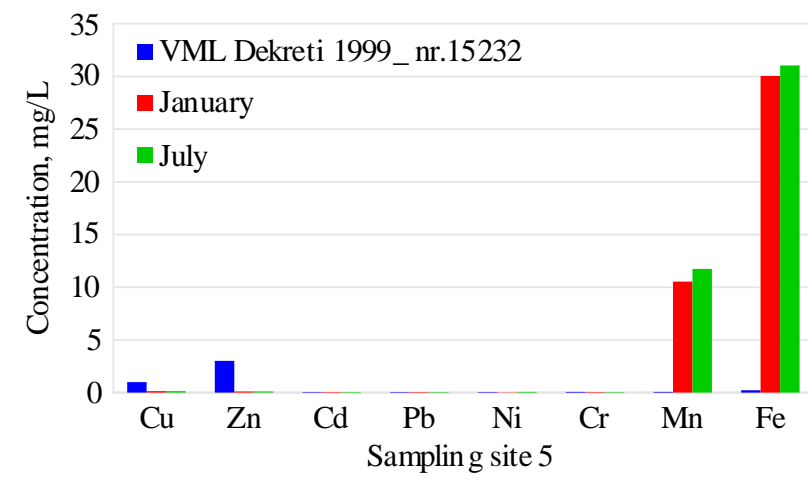

Figure 9. Concentration of heavy metals in sampling site $S_{5}$ (January, July 2020)

Compared to January (Table 2), the situation with heavy metal concentration in July is worse because the volume of water during the summer peak is lower, therefore the concentration of heavy metals is higher than in January. Table 5 shows the July 2020 data about the quality of drinking water, taken for analysis from the source located in the research area.
Table 5. Concentration of heavy metals in the source of drinking water, July 2020

\begin{tabular}{llcc}
\hline \multicolumn{1}{c}{ Heavy metals } & \multirow{2}{*}{ Unit } & VML & \multirow{2}{*}{ UA_16_2012 } \\
\hline Copper $\left(\mathrm{Cu}^{2+}\right)$ & $\mathrm{mg} / \mathrm{L}$ & 2.00 & 0.003 \\
Zink $\left(\mathrm{Zn}^{2+}\right)$ & $\mathrm{mg} / \mathrm{L}$ & $0.50^{*}$ & 0.008 \\
Cadmium $\left(\mathrm{Cd}^{2+}\right)$ & $\mathrm{mg} / \mathrm{L}$ & 0.005 & 0.006 \\
Lead $\left(\mathrm{Pb}^{2+}\right)$ & $\mathrm{mg} / \mathrm{L}$ & 0.01 & 0.012 \\
Nickel $\left(\mathrm{Ni}^{2+}\right)$ & $\mathrm{mg} / \mathrm{L}$ & 0.02 & 0.014 \\
Chrome $\left(\mathrm{Cr}^{3+}\right)$ & $\mathrm{mg} / \mathrm{L}$ & 0.05 & 0.004 \\
Manganese $\left(\mathrm{Mn}^{2+}\right)$ & $\mathrm{mg} / \mathrm{L}$ & 0.05 & 0.013 \\
Iron $\left(\mathrm{Fe}^{2+}\right)$ & $\mathrm{mg} / \mathrm{L}$ & 0.20 & 0.021 \\
\hline
\end{tabular}

$* \mathrm{Zn}$ reference value is based on United States Environmental Protection Agency (US EPA)

Concentrations of $\mathrm{Cd}$ at $0.006 \mathrm{mg} / \mathrm{L}$ and $\mathrm{Pb}$ at $0.012 \mathrm{mg} / \mathrm{L}$ (Fig. 10) indicate that the reference values were exceeded.

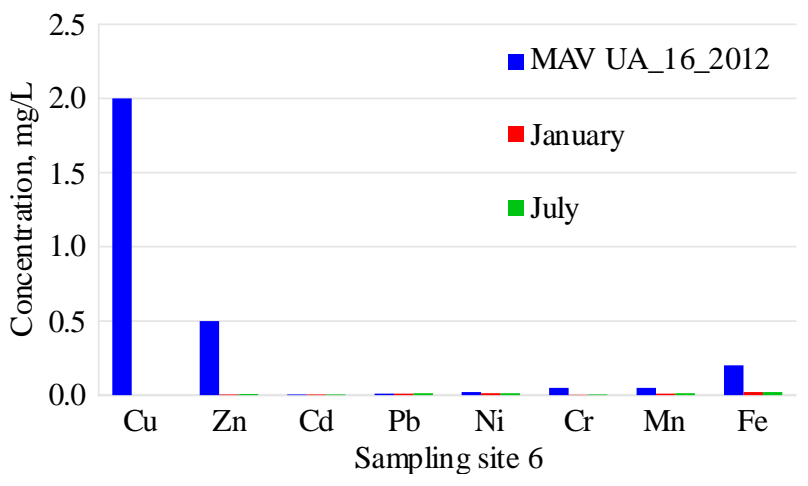

Figure 10. Concentration of heavy metals in sampling site $S_{6}$ (January, July 2020)

However, compared to surface waters, where the exceedance of reference values for heavy metals varied from January to July; in sampling site $S_{6}$, the difference in the concentration of heavy metals between winter and summer is not pronounced.

\section{Conclusions}

Existence of the Artana mine and its intensive exploitation since ancient times has caused the pollution not only of the Marec river waters, but also of the nearby environment in general. Therefore, our research aimed to determine the concentration degree of such heavy metals as $\mathrm{Pb}, \mathrm{Zn}, \mathrm{Ni}, \mathrm{Fe}$, $\mathrm{Cd}, \mathrm{Cu}, \mathrm{Mn}$ and $\mathrm{Cr}$ in the waters of this river and the drinking water from a single source located in the area of the industrial complex. During our research, we have ascertained a significant presence of heavy metals in the Marec river waters, as a result of water discharges from mining, flotation and drai-nage from landfills.

The research was conducted in January and July 2020, and, in order to create a more representative picture, we analyzed water taken from six sampling sites. The samples taken for analysis, except for $\mathrm{Cr}$, have confirmed a significant presence of heavy metals in the Marec river waters, while the discharge waters from the mine and the landfill drainage create an extremely serious and alarming situation for the environment in this area, as evidenced by the tabular data.

The waters taken at the sampling site $S_{1}$ prior to the industrial complex reflect the state without anthropogenic influences, with the exception of a low $\mathrm{Pb}$ concentration; which best indicates the potential sources of pollution in other sampling sites. 
To illuminate the seriousness of the situation caused by heavy metal pollution of the Marec river waters and the environment in general for the Ministry of Environment and Spatial Planning and the head administration of the Artana mine, it is critical to raise public awareness and commitment to taking measures so that the causes of water pollution of this river and the environment in general should be eliminated.

\section{Acknowledgements}

For the understanding, assistance and support that were vital for the most successful realization of this work, we extend our gratitude to the technical staff of the laboratory at HMIK (Hydrometeorological Institute of Kosovo), who demonstrated special dedication and care while conducting analysis of the samples.

Special thanks are also addressed to the staff of this journal's editorial office, for mutual cooperation and the given opportunity to publish this paper.

\section{References}

[1] Kadriu, S., Sadiku, M., Kelmendi, M., Mulliqi, M., Aliu, M., \& Hyseni, A. (2019). Scale of pollutions with heavy metals in water and sediment of River Ibër from landfill in Kelmend, Kosovo. Mining Science, (26), 147-155. https://doi.org/10.37190/msc192610

[2] Kadriu, S., Sadiku, M., Kelmendi, M., \& Sadriu, E. (2020). Studying the heavy metals concentration in discharged water from the Trepça Mine and flotation, Kosovo. Mining of Mineral Deposits, 14(4), 47-52. https://doi.org/10.33271/mining 14.04.047

[3] Raport Hotspotet Mjedisore në Kosovë. (2011). Agjencia për Mbrojtjen e Mjedisit të Kosovës. Prishtinë, Kosovës: Agjencia për Mbrojtjen e Mjedisit të Kosovës. Available at: https://www.ammkrks.net/repository/docs/raporti_i hotospoteve shqip_18122012.pdf

[4] Schmitt, O.J. (2009). Skënderbeu. Përkthimi në shqip me ndihmën Swiss Agency for Development and Cooperation SDC. Retrieved from https://peshkupauje.com/t/i-pafani-skenderbej-i/3883

[5] Kadriu, S., Sadiku, M., Kelmendi, M., \& Shala, A. (2021). The impact of polluting sources on the physical-chemical properties of water in the curved river in Kosovo. Journal of Environmental Treatment Techniques, 9(2), 368-374. https://doi.org/10.47277/JETT/9(2)374

[6] Bogdanović, G., Antonijević, M., Milanović, Z., Šerbula, S., \& Milić, S. (2007). Analiza stanja rudničkih voda Rudnika bakra Bor. In II Simpozijum "Reciklažne tehnologije i održivi razvoj” (pp. 269-275). Soko Banja, Srbija.

[7] Sadiku, M., Kadriu, S., Kelmendi, M., \& Aliu, M. (2020). Ndikimi i ujërave të minierës dhe deponive industriale të Artanës në ndotjen mjedisore. In $2^{\text {nd }}$ international Multidisciplinary Geosciences Conference. Geosciences and Sustainable Development (pp. 142-147). Mitrovicë, Kosovo.

[8] Kadriu, S., Malollari, I., Beqiri, L., Aliu, M., Sadiku, M., Baruti, B., \& Kelmendi, M. (2017). Presence of heavy metals in water and sediment of rivers Trepca and Sitnica. Journal of Environmental Protection and Ecology, 18(1), 10-21.
[9] Hilson, G. (2000). Pollution prevention and cleaner production in the mining industry: an analysis of current issues. Journal of Cleaner Production, 8(2), 119-126. https://doi.org/10.1016/S0959-6526(99)00320-0

[10] Wei, W., Ma, R., Sun, Z., Zhou, A., Bu, J., Long, X., \& Liu, Y. (2018). Effects of mining activities on the release of heavy metals (HMs) in a typical mountain headwater region, the Qinghai-Tibet Plateau in China. International journal of Environmental Research and Public Health, 15(9), 1987. https://doi.org/10.3390/ijerph15091987

[11] Malik, N., Biswas, A.K., Qureshi, T.A., Borana, K., \& Virha, R.(2009). Bioaccumulation of heavy metals in fish tissues of a freshwater lake of Bhopal. Environmental Monitoring and Assessment, 160(1-4), 267-276. https://doi.org/10.1007/s10661-008-0693-8

[12] Çullaj, A. (2010). Kimia e mjedisit. Tirana, Albania.

[13] Sadiku, M., Shala, F., Hoda, S., Sadiku, A., Lajçi, N., \& Kadriu, S. (2016). Impact of zinc's cake in groundwater pollution. Journal of International Environmental Application \& Science, 11(1), 72-76.

[14] Kadriu, S., Sadiku, M., Kelmendi, M., Tahiraj, B., Aliu, M., Hyseni, A., $\&$ Shala, A. (2020). Research of the drinking water quality in wells and fountains of villages in gjakova municipality in Kosovo. Journal of Environmental Treatment Techniques, 8(3), 1151-1156.

[15] ISO 5667-6. (2014). Water quality - Sampling - Part 6: Guidance on sampling of rivers and streams.

[16] ISO 5667-11. (2009). Water quality - Sampling - Part 11: Guidance on sampling of groundwaters.

[17] ISO 5667-1. (2006). Water quality - Sampling - Part 1: Guidance on the design of sampling programmes and sampling techniques.

[18] ISO 5667-3. (2012). Water quality - Sampling - Part 3: Preservation and handling of water samples.

[19] APHA, AWWA, WEF. (2005). Standard methods for the examination of water and wastewater. New York, United States: American Public Health Association.

[20] EPA Method 3015. (1994). Microwave assisted acid digestion of aqueous samples and extracts. Pittsburgh, United States: Duquesne University.

[21] Udhëzimi Administrativë e MMPH-Nr. 30/2014 të Kosovës, për kushtet, mënyrat, parametrat dhe vlerat kufizuese të shkarkimit të ujërave të ndotura në rrjetin e kanalizimit publik dhe në trupin ujor. (2014). Available at: https://mmph.rks-gov.net/assets/cms/uploads/files/Publikimet/ Kalendari/ministri-ua-30-2014 785221.pdf

[22] Vlerat maksimale të lejuara për disa metale të rënda në ujërat sipërfaqësor sipas Dekretit Legjislativ 11 Maj 1999 Nr. 15232. (2015). Raport për gjendjen e ujërave në Republikën e Kosovës, Ministria e Mjedisit dhe Planifikimit Hapsinor. Prishtinë. Available at: https://www.ammkrks.net/repository/docs/Raporti i ujrave i 2015 shqip (2).pdf

[23] Udhëzimi Administrativ Nr. 16/2012. (2012). Për cilësinë e ujit për konsum nga njeriu, të Kosovës. Retrieved from https://gzk.rksgov.net/ActDetail.aspx?ActID=10134

[24] Halysh, V., Trus, I., Gomelya, M., Trembus, I., Pasalskiy, B., Chykun, N., Trokhymenko, G., \& Remeshevska, I. (2020). Utilization of modified biosorbents based on walnut shells in the processes of wastewater treatment from heavy metal ions. Journal of Ecological Engineering, 21(4), 128-133. https://doi.org/10.12911/22998993/119809

[25] Terrence, T., John, F., Shoichi, K., Darryl, J., Stephen, A., \& Philip, C. (2007). Chemical safety of drinking water: assessing priorities for risk management. Geneva, Switzerland: World Health Organization. Available at: https://apps.who.int/iris/bitstream/handle/10665/43285/ 9789241546768 eng.pdf

[26] Robards, K., \& Worsfold, P. (1991). Cadmium toxicology and analysis - A review. Analyst, 116(6), 549-568. https://doi.org/10.1039/an9911600549

\section{Вплив рудника Артана на забруднення річки Марек важкими металами у Косово}

\section{М. Садіку, С. Кадріу, М. Келменді, Л. Латіфі}

Мета. Аналіз ступеня впливу рудника Артана на забруднення вод річки Марек важкими металами на основі експериментальних досліджень відібраних проб.

Методика. Для реалістичної оцінки якості води річки Марек і одного джерела, розташованого в районі дослідження і використовуваного для пиття, застосовані стандартні методи: ISO 5667-6 для поверхневих вод та ISO 5667-11 для підземних вод. Відбір зразків в певній кількості, а також їх транспортування проводилися в повній відповідності з методом ISO 5667-1.3. Проби, відібрані для визначення важких металів, зберігалися відповідно до процедури консервації АРНА. Для вилучення (мінералізації) важких металів у відібраних пробах застосовувався метод ЕРА-3015А, а для визначення концентрації важких металів - метод вимірювання SAA (атомно-абсорбційна спектрофотометрія).

Результати. В результаті промислової діяльності на руднику Артана було встановлено, що основною причиною забруднення вод річки Марек і навколишнього середовища $є$ діяльність з видобутку корисних копалин в цьому промисловому комплексі. Встановлено значну присутність важких металів у водах річки Марек у результаті скидів гірничодобувних, флотаційних і дренажних вод зі звалищ. Аналіз проб води, що скидається з шахти, після флотації та осушення полігонів показує значне перевищення концентрації важких металів на всіх ділянках відбору проб. 
Наукова новизна. Отримано реалістичні дані щодо ступеня концентрації важких металів у водах річки Марек в січні і липні 2020 року, що характеризує шкідливий вплив гірничодобувної промисловості.

Практична значимість. Рекомендується Міністерству охорони навколишнього середовища і керівництву рудника Артана вжити термінових заходів щодо усунення причин забруднення води цієї річки і навколишнього середовища в цілому.

Ключові слова: рудник Артана, річка Марек, флотачія, звалище, аналіз води, важкі метали, забруднення

\section{Влияние рудника Артана на загрязнение реки Марек тяжелыми металлами в Косово}

\section{М. Садику, С. Кадриу, М. Кельменди, Л. Латифи}

Цель. Анализ степени влияния рудника Артана на загрязнение вод реки Марек тяжелыми металлами на основе экспериментальных исследований отобранных проб.

Методика. Для реалистичной оценки качества воды реки Марек и одного источника, расположенного в районе исследования и используемого для питья, применены стандартные методы: ISO 5667-6 для поверхностных вод и ISO 5667-11 для подземных вод. Отбор образцов в определенном количестве, а также их транспортировка производились в полном соответствии с методом ISO 5667-1.3. Пробы, отобранные для определения тяжелых металлов, сохранялись в соответствии с процедурой консервации АРНА. Для извлечения (минерализации) тяжелых металлов в отобранных пробах применялся метод ЕРА-3015А, а для определения концентрации тяжелых металлов - метод измерения SAA (атомно-абсорбционная спектрофотометрия).

Результаты. В результате промышленной деятельности на руднике Артана было установлено, что основной причиной загрязнения вод реки Марек и окружающей среды является деятельность по добыче полезных ископаемых в этом промышленном комплексе. Установлено значительное присутствие тяжелых металлов в водах реки Марек в результате сбросов горнодобывающих, флотационных и дренажных вод со свалок. Анализ проб воды, сбрасываемой из шахты, после флотации и осушения полигонов показывает значительное превышение концентрации тяжелых металлов на всех участках отбора проб.

Научная новизна. Получены реалистичные данные относительно степени концентрации тяжелых металлов в водах реки Марек в январе и июле 2020 года, характеризующие вредное влияние горнодобывающей промышленности.

Практическая значимость. Рекомендуется Министерству охраны окружающей среды и руководству рудника Артана принять срочные меры по устранению причин загрязнения воды этой реки и окружающей среды в целом.

Ключевые слова: рудник Артана, река Марек, флотачия, свалка, анализ воды, тяжелье металлы, загрязнение 